\title{
The Influence of Interest in Choosing the Mechanical Engineering Vocational Program in Vocational High Schools
}

\author{
Putri Wulan Juliana ${ }^{1}$, Thomas Sukardi ${ }^{2}$ \\ ${ }^{1}$ Mechanical Engineering Department, Master Program, Yogyakarta State University, Indonesia \\ Email: putri.wulan2016@student.uny.ac.id \\ ${ }^{2}$ Faculty of Engineering, Yogyakarta State university, Indonesia \\ Email: thomas_sukardi@uny.ac.id
}

(Received: January-2019; Reviewed: March-2019; Accepted: April-2019; Published: April-2019)

(02019 - EST Graduate Program Universitas Negeri Makassar. This is an article with open access under license CC BY-NC-4.0 (https://creativecommons.org/licenses/by-nc/4.0/).

\begin{abstract}
This research aimed to find out the influence of students' interests in choosing the mechanical engineering vocational program. The research method used was descriptive quantitative. The population in this study were all Grade X students in Yogyakarta which total number were 180 respondents. The data collecting technique was using questionnaires which then was analyzed using descriptive analysis and regression. The results of this study were (1) Students' interests in choosing mechanical engineering vocational program was high. (2) There was a positive and significant influence from students' own understanding, family, school, and society towards students' interests in choosing the mechanical engineering vocational program, (3) The four variables, together, have positive and significant influences towards vocational high school students' interests in choosing the mechanical engineering vocational program in Yogyakarta..
\end{abstract}

Keywords: vovational program, students' interests, ex post facto, descriptive quantitative

\section{INTRODUCTION}

Vocational education is a specialized education which is prepared to educate a person to be able to work in a particular job field such as, industry, agriculture, mining, etc. According to Mortaki (2012, p.51) vocational education is a form of educational system which aims to make a person to have a professional qualification, artistic sense, or a particular job. Therefore, the person will be able to develop the skills that he/she has acquired. While in constitution No. 20 year 2013 about National Educational System, article 15 shows that vocational education which is applied to prepare the students to be able to work directly in a particular job field. Vocational high school according to Sudira (2009) has several advantages such as: (1) able to improve self-quality, improving the chances in seeking a job, and applying for the higher education degree: (2) helping to produce high quality manpower: (3) decreasing unemployment.

In the ASEAN Economic Community (MEA), Indonesia has entered the challenge of labor market competition. MEA will have a significant influence towards man powers in vocational sectors. Therefore, the government is trying to change the total ratio of vocational school and general high school from 30:70 to 70:30 until the end of 2015. Vocational High 
School or SMK is expected to be able to give graduate outputs who have qualifications which correspond with the industrial needs. However, the problem now is that the students' interest in choosing vocational educational has yet to reach the optimum number. It has to be known that the person is truly learning the specific skill that she/she has chosen when learning in SMK or not. It has a purpose which is to find out solutions to the problem of SMK graduates who have low qualifications or cannot fulfill the industrial needs. An expertise in a field needs an in-depth learning so the person is expected to understand his/her own skill and ability. While still in SMK, students who attend will be faced with the problem of choosing the vocational program. This has to be suitable with one's own interest, skill, and ability. If the student choose a program which his interest, he/she will have a hard time following the lesson in the vocational competence. Bambang Sartrio Lelono from "Dirjen Pembinaan Pelatihan dan Produktivitas" states that there are two problems related to the working world which are related to ready-towork man powers such as, under qualification and link and match in the industrial world (Latief, 2017).

Vocational High School is an institution which function is to prepare graduates who are ready to work, However, data from the Central Statistic Institution (BPS) show otherwise. Data from BPS in February 2018 shows a problem that the number of open unemployment of SMK graduates were $8.92 \%$. It is slightly higher than that of general high school (SMA) graduates which were $7.19 \%$. This high number of unemployment for the SMK graduates needs an immediate action by the government and the industrial world. This problem is caused by the SMK which produce ready-to-work man powers fails to prepare any man powers who is suitable with the current needs of the industrial world. Research by Vacilescu (2014) which found that there are a weak self-awareness of vocational interests, so that the selection of educational is still found to be incompatible with personal vocational interests, which can lead professional scholl failure. "Dirjen Pembinaan Pelatihan dan Produktivitas" stats that SMK graduates is still at most out of job and the results provided are not satisfactory, which is still no maximally supported by the government and industry (Latief, 2017).

The school will help the students to know about the existing vocational programs.
Sccroding to Slameto $(2013$, p.180) interest and its relation with any learning activities are affecting the students' learning process. Daradjat (2005, p.133) adds that interest is a mental tendency to stay at one expertise which is considered to be precious for the person. While interest, according to Bimo Walgito (2010, p.38) is a state that happens to a person who shows a caring action to something which is then followed by wanting to know and to learn more about it. Interests based on Sari (2016), namely the tendency to do or choose something that comes from experience and translation of what is seen, heard, and felt. Basically, interest will appear in individuals as a learning process that is carried out continuously and is based on a high sense of curiosity. As research conducted by Mustata Andreaa-Elena (2013) that this study found the fact that the formation of vocational interest in adolescents is not differentiated by gender but they form interests and direct themselves according to fields that are considered to bring certain benefits. In addition, research conducted by Dharmayanti (2014) shows that interest will appear due to the factors of self understanding, student environment, and vocational image both partially and simultaneously.

How interest appears in a person is explained by Slameto $(2013$, p.181) in which the needs intensity which was done by a person will significantly influence how big a person's interest is. Therefore, the appearance of interest is based on the needs and the activities that will be done by the person. Interest has factors that can give influence, like what is explained by Djaali (2012, p.132) that there are intrinsic factors which affecting a person's interest from the inside such as, physical and spiritual. Besides, there extrinsic factors such as, families, schools, and societies. While Naiafian (2013) states that factors which influence interest are intrinsic factors of a person which are parents factor, friends factor, teachers factor, media factor, and school data factor.

This research is focused on Mechanical Engineering department in Vocational High Schools. Therefore, vocational interest has a significant influence for every child in choosing the vocational program. Vocational Interest according to Djaali (2017) is a tendency of a person to desire a job prospect or a particular position suitable with his/her personal characteristics. This statement is also supported by Finch (1984) who says that determining the 
vocational interest factor is really important to know how far a person has planned his/her education to achieve a particular job in line with his/her ability. About Skill competence according to Djaali (2017) is a competence, a skill, as well as an activity of an individual. The statement supported with past research by Igbinedion (2011) stated that interest is an important factor to choose vocational school. Measurement of a personal interest is basically to determine the response of the person to choose a career or a particular skill program.

This research is supported by several past researches which were done by Novandreas Iskandar (2016) resulted in the factors which influence SMK students to choose Mechanical Engineering department are internal factors such as, physics, psychology, and exhaustion, while the external factors are family and school. Another research was done by Daiya Bukantaite (2006) which found that students' motive to choose vocational high school are low average scores, prospect to be professionally independent, low studying weight, and insufficient knowledge about their options of the eligible vocational high school. Vocational interest or career orientation doesn't have any relation with genders stated by Mustata AndreeaElena (2013). Winna Dharmayanti (2014) also conducted a similar research. She found that junior high school students' interest to apply to SMK is in "good" category. There is a significant influence from personal knowledge, the society, and the fame of SMK towards junior high school students' interest to apply in SMK. Another research by Rahdiyanta (2017) which found that the direct effect of the family environment and school environment on the choice of mechanical engineering expertise programs in VHSs is not significant. This research studied interest and its influence in four factors which are personal knowledge, family, school, and society.

The choosing of vocational program, according to London (1973, p.74) is a mixed process between interest, ability, score, opportunity, hope, and the limitation of reality. Therefore, intensive information needs to be provided by family, school, and even society related to choosing of vocational program. Based on the existing researches and relating it to the existing problem of the field, this research focused on personal knowledge factor, family factor, school factor, and society factor. The higher the students' interest toward mechanical engineering vocational program, the number of students and SMK graduates who are experts at machines will also be higher. This research has a benefit of improving the fame of SMK in the eyes of society so that it could attract students, parents, and stakeholders. Besides, the understanding of the vocational interest would help the schools in attracting new students. The students' interest in choosing this vocational program is needed in order for the students to not make a mistake in choosing a vocational program and SMK will produce high quality output to fulfill the needs of industrial world.

\section{METHOD}

This research was an ex-post facto. The approach that was used in this research were descriptive quantitative and correlations. The data of each variable were analyzed the influence and the influence level between two variables or several variables which were reflected in coefficient correlation. There were four independent variables: personal knowledge, family, school, and society. The dependent variable was students' interest in joining the mechanical engineering vocational program in Vocational High School (SMK).

The population in this research were grade X students of SMK in Yogyakarta. The total number were 324 students. The samples were calculated using Slovin's formula with 5\% margin of error resulting 180 respondents. Samples were chosen using proportional random sampling technique. The data collection technique used was questionnaire with Likert scale 4 answer choices. The validity and reliability were analyzed theoretically and empirically. The collected data were analyzed using simple linear regressive descriptive analysis technique and multiple linear regressive descriptive analysis to prove the research hypothesis. Normality test, linearity test, and multicolinearity test were done to fulfill the hypothesis testing requirement.

\section{RESULT AND DISCUSSION}

The data collected from this research were then described in frequency distribution and percentage. The result of the analysis included mean, median, modus, and primary deviation, then were followed with deciding the variable order based on the tendency category of each variable. 
Table 1. Frequency Distribution and Percentage of Students' Interest to Choose Mechanical engineering vocational program

\begin{tabular}{lcc}
\hline \multicolumn{1}{c}{ Category } & Frequency & Percentage \\
\hline Very High & 53 & $29 \%$ \\
High & 66 & $37 \%$ \\
Low & 51 & $28 \%$ \\
Very Low & 10 & $6 \%$ \\
\hline
\end{tabular}

According to Table 1, there were $66 \%$ SMK students of mechanical engineering showing interest in mechanical engineering vocational program. Then, the data were analyzed to decide the influence of the dependent variable and the independent variable by using simple linear regressive analysis and multiple linear regressive analysis. From the result of the research, the influence level of the research variables could be seen on Table 2 and Table 3 .

Table 2. Result of Multiple Linear Regressive Analysis

\begin{tabular}{lcccc}
\hline Var & $\begin{array}{c}\text { Adjus } \\
\text { ted } \mathbf{R}^{\mathbf{2}}\end{array}$ & Const & Coeff. & Sig. \\
\hline $\mathrm{X}_{1}$, & & & $\mathrm{X} 1=0,573$ & \\
$\mathrm{X}_{2}$, & 0,562 & $-2,156$ & $\mathrm{X} 2=0,163$ & 0,000 \\
$\mathrm{X}_{3}$, & & & $\mathrm{X} 3=0,357$ & \\
$\mathrm{X}_{4}$ & & & $\mathrm{X} 4=0,145$ & \\
$-\mathrm{Y}$ & & & & \\
\hline
\end{tabular}

Table 2 showed that there is an influence from personal knowledge, family, school, and society towards SMK students' interest in choosing the mechanical engineering vocational program. The level could be concluded from the coefficient value of determinant $\mathrm{R}^{2}$ which was 0.562 or $56.2 \%$. For the independent variables, the scores were 0.573 for personal knowledge, 0.163 for family, 0.357 for school, and 0.145 for society. Based on the result, it was proven that personal knowledge, family, school, and society were comprehended by SMK students and became important aspects. They contributed significantly in making the students' interest in choosing mechanical engineering vocational program. The influence of each independent variable towards dependent variable could be seen on the following Table 3 .
Table 3. Result of Simple Linear Regressive Analysis

\begin{tabular}{ccccc}
\hline Var & $\mathbf{R}^{\mathbf{2}}$ & Const & Coeff. & Sig. \\
\hline $\mathrm{X}_{1}-\mathrm{Y}$ & 0,392 & 12,184 & 0,891 & 0,000 \\
$\mathrm{X}_{2}-\mathrm{Y}$ & 0,200 & 23,126 & 0,453 & 0,000 \\
$\mathrm{X}_{3} \mathrm{Y}$ & 0,370 & 15,385 & 0,661 & 0,000 \\
$\mathrm{X}_{4}-\mathrm{Y}$ & 0,202 & 21,717 & 0,611 & 0,000 \\
& & & & \\
\hline
\end{tabular}

Table 3 informed us that (1) there is a positive and significant influence from personal knowledge towards SMK students' interest in choosing mechanical engineering vocational program with the score of $\mathrm{R}^{2}$ (coefficeient of determination) 0.392 or $39.2 \%$; (2) there is a positive and significant influence from family towards SMK students' interest in choosing mechanical engineering vocational program with the score of $\mathrm{R}^{2} 0.200$ or $20 \%$; (3) there is a positive and significant influence from school towards SMK students' interest in choosing mechanical engineering vocational program with the score of $\mathrm{R}^{2} 0.370$ or $37 \%$; and (4) there is a positive and significant influence from society towards SMK students' interest in choosing mechanical engineering vocational program with the score of $\mathrm{R}^{2} 0.202$ or $20.2 \%$.

Based on the descriptive analysis and simple linear regressive analysis, data for students' personal knowledge showed a 39.2\% positive and significant influence towards students' interest in choosing a vocational program. The mean score of personal knowledge was 32.03 and in "high" category which was $41 \%$. The result of this research was supported by other research result done by Dharmayanti and Munadi (2014), Sari and Munadi (2017) and Nurmala (2012). Dharmatanti and Munadi (2014) stated that there was a positive and significant influence from the personal knowledge factor towards Junior High School students' interest to apply to SMK in Pontianak with $\mathrm{r}$ score of 0.743 ; and $\mathrm{p}$ score of 0.000 . The research done by Sari and Munadi (2017) proved that personal knowledge has a positive and significant influence towards Junior High School students' interest to apply to SMK. Nurmala (2012) which suggested that there is a positive effect of self knowladge to grade IX SMP students interest to continue their study to SMK in the healthcare expertise. Personal knowledge was the main factor that influenced a person to choose every activity which would be done because it was supported by the physical condition, intelligence 
level, good psychological condition, and life's goal or future plan. Students who were able to understand himself/herself would be able to develop his/her ability appropriately.

Data for family variable showed a $20 \%$ positive and significant influence towards students' interest to choose a vocational program. The mean score for this variable was 38.83 and in "high" category which was $53 \%$. This result was supported by another research result by Iskandar (2016) which suggested that there was a positive and significant influence from family factor toward SMK students' interest to choose mechanical engineering vocational program up to $77.2 \%$. Family was an external factor which functioned as the first environment that shaped a child's personality and talent. A child spent much of his/her time to interact with family members. So family was the first to provide knowledge, information, and insight which were needed for the child's future. Therefore, in choosing the vocational program in SMK, family's influence was big as the one who directs the child's interest. Family always gave motivation and positive support towards a child's development so he/she could find his/her true self.

Data for school variable showed a $37 \%$ positive and significant influence towards students' interest to choose a vocational program. The mean score for this variable was 38.36 and in "low" category which was $46 \%$. This result was also supported by Iskandar (2016) which proved that the external factor school had $82.3 \%$ influence towards the students' interest to choose mechanical engineering vocational program. Another research result by Santoso (2014) proved that SMK advertisement and location significantly contributed to junior high school students in Semarang choosing to continue to SMK. School was also an external factor which became a media for students to develop their own potential and the career that was chosen was based on their interest, ability, and capacity. Students were given direction to plan their future and find the suitable job according to their interest and ability.

Data for society variable showed there was a $20.2 \%$ positive and significant influence towards the students' interest to choose a vocational program. The mean score for this variable was 31.11 and in "low" category which was $43 \%$. This showed that SMK had a poor reputation in the eyes of society. Sukardi (2008) stated that SMK was still seen by the society as an educational institute which was not less prestigious than general senior high school. There was also a general statement that students who enroll in SMK are those who have low academic achievements. Therefore, a counseling was needed to introduce SMK to society so that it could become a proper place to develop the children's ability to be ready to work, not as an alternative when children couldn't be accepted in general senior high school or had a low academic achievement.

\section{CONCLUSION AND SUGGESTION}

Based on the result of analysis, it can be concluded that: (1) SMK students' interest in choosing mechanical engineering vocational program was $66 \%$ in "high" category; (2) variables which have been proven to be having a positive and significant influence towards the students' interest to choose mechanical engineering vocational program were personal knowledge, family, school. And society. (3) The four variables, together, can improve the students' interest to choose mechanical engineering vocational program so it can give maximum learning outcomes which in the end can improve the quality of man power and have an expertise which was needed by the current industrial needs.

The personal knowledge, family environment, school environment, and society environment have important roles in determining of interest in choosing the mechanical engineering vocational program in vocational high schools. Students should always be able to increase their capacity by look for information from many resources. In addition, the school must intensify promotional activities for society to introduce vocational education.

\section{REFERENCES}

Andreea, M., \& Elena. (2013). The role of gender in the formation of vocational interests and career orientation in adolescence. Procedia Social and Begavioral Sciences, 127 (2014), 240-244.

Bukantaite, Daiva., Habil, RL., \& Tomas, S. (September 2006). Motivation for Vocational Education and Training Choice in Lithuania. Paper presented at the European Confernce on Educational Research Post Graduate 
and New Researcher Pre-Conference, University of Geneva.

Daradjat, Zakiah. (2005). Pendidikan Islam dalam Keluarga dan Sekolah. Jakarta: Ruhama.

Dharmayanti, W., \& Sudji, M. (2014). Faktorfaktor yang mempengaruhi minat siswa SMP masuk SMK di kota Pontianak. Jurnal Pendidikan Vokasi, 4(3). https://journal.uny.ac.id/index.php/jpv/ article/view/2563

Djaali. (2012). Psikologi Pendidikan (6 $6^{\text {th }}$ ed.). Jakarta: Bumi Aksara.

Djaali. (2017). Psikologi Pendidikan $\left(10^{\text {th }}\right.$ ed.). Jakarta: Bumi Aksara.

Finch, R. Curtis \& Crunkilton R. John. (1984). Curriculum Development in Vocational and Technical Education: Planning, Content, and Implementation. Boston: Allyn and Bacon. Inc

Igbinedion, V. I. (2011). Perception of Factors that Influence Students' Vocational Choice of Secretarial Studies in Tertiary Institutions in Edo State of Nigeria. European Journal of Educational Studies, 3(2).

Iskandar, Novandreas., Agus, S., \& Kamin, S. (2016). Identifikasi Faktor-Faktor yang Mempengaruhi Siswa SMK Memilih Program Keahlian Teknik Mesin. Journal of Mechanical Engineering Education, 3(2).

Latief. (2017, Agustus 29). Jangan Lupakan SMK. Retrieved from https://edukasi.kompas.com/read/2017 /08/29/17582511/jangan-lupakan-smk

London, H. (1973). Principles and techniques of vocational guidance. Columbus, Ohio: Charless E. Merrill Publishing Co.

Mortaki, Sapfo. (2012). The Contribution of Vocational Education and Training in the Preservation and Diffusion of Cultural Heritage in Greece: The Case of the Specialty "Guardian of Museums and Archaeological Sites". International Journal of Humanities and Social Science, 2(24).

Najafian, M. dkk. (2013). Factors Affecting Increase (decrease) in Interest and
Guiding Students Towards Higher Education. Australian Journal of Basic and Applied Sciences, 7(7), 980-985.

Nurmala, S. (2012). Faktor-Faktor yang Mempengaruhi Minat Siswa Kelas IX SMP untuk melanjutkan ke SMKN 2 Simpang Empat Kompetensi Keahlian Perawat Kesehatan Kabupaten Tanah Bambu. Thesis, unpublished. Universitas Negeri Yogyakarta

Rahdiyanta, Dwi. (2017). The Effects of Situational Factors on The Choice of The Mechanical Engineering Expertise Program in Vocational High Schools. Jurnal Pendidikan Vokasi, 7(2), 180192.

http://journal.uny.ac.id/index.php/jpv.

Santoso, Jarot Tri Bowo. (2014). Faktor Faktor yang Mempengaruhi Siswa SMP N di Kota Semarang Memilih SMK. Jurnal Pendidikan Ekonomi Dinamika Pendidikan. 9(1), 1-20. https://journal.unnes.ac.id/nju/index.ph $\mathrm{p} / \mathrm{DP} /$ article/view/3352/3268

Sari, Dian Purnama., \& Sudji Munadi. (2017). Factors Affecting Junior High School Students' Interest in Continuing to Vocational High School in Magelang District. Jurnal Pendidikan Vokasi, 7(2), 193-202. http://journal.uny.ac.id/index.php/jpv.

Slameto. (2013). Belajar dan Faktor-Faktor yang Mempengaruhi. Jakarta: Rineka Cipta.

Sudira, Putu. (2009). Pendidikan Vokasi Suatu Pilihan (online). https://blog.uny.ac.id/putupanji/2009/0 3/17/pendidikan-vokasi-suatu-pilihan/

Sukardi, Dewa Ketut., \& Nila K. (2008). Proses Bimbingan dan Konseling di Sekolah. Jakarta: PT Rineka Cipta.

Vasilescu, Carmen Camelia., Aurelia Moraru., \& Nicu Ionel Sava. (2014). The Relationship between Career Interests and Academic Major: A Comparative Analysis. Procedia Social and Behavioral Sciences, 187 (2015), 559564.

Walgito, Bimo. (2010). Pengantar Psikologi Umum. Yogyakarta: Andi Yogyakarta 